\title{
Adaptarea Job Stress Survey (JSS) în România: Implicaţii privind manifestări ale stresului ocupaţional în România
}

\author{
Dragoş lliescu ${ }^{1}$ \\ SNSPA-FCRP Bucureşti, Departamentul de Psihologie / D\&D Testcentral România \\ Raluca Livinţi \\ D\&D Testcentral România \\ Horia D. Pitariu \\ Universitatea Babeş-Bolyai Cluj-Napoca, Facultatea de Psihologie şi Ştiinţele Educaţiei
}

\begin{abstract}
The paper discusses the cultural adaptation of the Job Stress Survey in Romania, describing the translation and adaptation process, the structure of the Romanian normative sample and the psychometric characteristics of the Romanian form of the measure. Also, conclusions drawn are discussed regarding implications of the normative sample, in terms of comparisons between certain criterion groups contained in the normative sample, as well as in terms of comparisons of the Romanian and US data regarding the experience of occupational stress.
\end{abstract}

Keywords: occupational stress, cultural adaptation, Job Stress Survey

\section{Résumé}

L'article traite l'adaptation culturelle du Job Stress Survey en Roumanie, en décriant la procédure d'adaptation, la composition de l'échantillon normatif et les caractéristiques psychométriques de la version adaptée de l'instrument. De même, on énonce aussi les conclusions qui résultent des données normatives roumaines, en terme de comparaison entre quelques groupes - critère de cet échantillon normatif, mais aussi en ce qui concerne la comparaison des manifestations liées au stress occupationnel résultant de l'échantillon américain.

Mots-clés: stress occupationnel, adaptation culturelle, Job Stress Survey

\section{Rezumat}

Articolul discută adaptarea culturală a Job Stress Survey în România, comentând procesul de adaptare, componenţa eşantionului normativ şi caracteristicile psihometrice ale formei adaptate a instrumentului. De asemenea, se discută concluzii şi implicaţii care rezultă din datele normative româneşti, atât în termenii comparaţiilor între anumite grupuri-criteriu din interiorul acestui eşantion normativ, cât şi în ceea ce priveşte comparaţia manifestărilor legate de stresul ocupaţional, rezultate din eşantionul american.

Cuvinte cheie: stres ocupaţional, adaptare culturală, Job Stress Survey

Efectele şi costurile directe (de exemplu absenteismul şi fluctuaţia de personal), precum şi cele indirecte (de exemplu reducerea productivităţii şi diminuarea calităţii serviciilor oferite clienţilor) pe care stresul le are asupra organizaţiilor sunt îngrijorătoare prin amploarea lor şi au devenit de mult timp un obiect al atenţiei pentru manageri şi legiuitori, precum şi un obiect de studiu pentru cercetătorii din domeniul

\footnotetext{
${ }^{1}$ Adresa de corespondenţă: dragos.iliescu@testcentral.ro
}

ştiinţelor comportamentale. La fel au fost studiate şi efectele pe care stresul ocupaţional le are asupra sănătăţii fizice şi psihice a angajaţilor.

Eforturile de studiere a fenomenului stresului s-au folosit de la bun început de instrumente de măsurare a acestui fenomen, instrumentele de măsurare a stresului ocupaţional fiind utile nu doar în cercetarea ştiinţifică fundamentală realizată în acest domeniu, ci, de asemenea, în cercetarea aplicată, realizată în cazuri specifice, cu scopuri de înţelegere şi asanare a unor realităţi 
evidente din organizaţii clar definite. Ca atare, în jurul acestor eforturi de măsurare a stresului ocupaţional s-au format diverse teorii şi instrumente de măsurare, fiecare cu plusurile şi minusurile sale. Dintre teoriile cu impact major asupra măsurării stresului este important să menţionăm Teoria Potrivirii Persoană-Mediu (Person-Environment Fit, P-E Fit; French \& Caplan, 1972; French, Caplan \& Harrison, 1982), Modelul Solicitare-Control (Demand Control model; Karasek, 1979) şi Teoria Tranzacţională a Stresului (Lazarus, 1991). Conform teoriei potrivirii, stresul şi tensiunea la locul de muncă sunt atribuite interacţiunii individului cu mediul său de lucru. Conform modelului solicitare-control, acestea reies din interacţiunea pe care solicitările sau presiunile obiective ale mediului de lucru o au cu libertatea decizională a angajatului în îndeplinirea sarcinilor sale la locul de muncă (Edwards \& Cooper, 1990). Conform teoriei tranzacţionale, stresul este un proces care presupune o tranzacţie între individ şi mediul său de lucru, fiind influenţat de factorii de stres (care sunt condiţiile stresante antecedente), de maniera în care sunt aceştia evaluaţi de către o anumită persoană şi de resursele de gestionare ale individului.

Din aceste teorii au rezultat instrumente specifice de măsurare a stresului ocupaţional. De exemplu, pe baza teoriei potrivirii persoană-mediu s-a dezvoltat Scala mediului de lucru (Work Environment Scale, WES; Insel \& Moos, 1974). Pe baza teoriei potrivirii persoană-mediu a fost construit Inventarul stresului ocupaţional (Occupational Stress Inventory; Osipow \& Spokane, 1987; Osipow, 1998). Ca instrument eclectic, tributar ambelor acestor teorii, a apărut Chestionarul de diagnosticare a muncii (Job Diagnostic Survey, JDS; Hackman \& Lawler, 1971; Hackman \& Oldham, 1975). Teoria tranzacţională a dat naştere, printre altele, Indicatorului stresului ocupaţional (Occupational Stress Indicator, OSI; Cooper, Sloan \& Williams, 1988).

Aceste instrumente însă nu sunt perfecte, iar problemele legate de măsurarea stresului ocupaţional nu au putut fi tranşate de acestea, aşa cum relevă criticile aduse lor. De exemplu, Dewe (1989) observa că unul dintre cele mai accentuate puncte negative ale tuturor acestor chestionare este legat de faptul că nu se acordă suficientă atenţie unor factori precum intensitatea, frecvenţa şi semnificaţia care sunt atribuite evenimentelor stresante din mediu. $\mathrm{Ca}$ atare, recomanda evaluarea atât a severităţii percepute a surselor specifice de stres ocupaţional, cât şi a frecvenţei resimţirii de către indivizi a fiecărui factor de stres ocupaţional.

\section{Chestionarul: Job Stress Survey}

Job Stress Survey (JSS, Chestionarul Stresului Ocupaţional; Spielberger \& Vagg, 1999) a fost creat pentru a rezolva această problemă, care nu este una conceptuală, ci una metodologică, de măsurare. Acest chestionar fost construit cu intenţia de a evalua sursele generale ale stresului ocupaţional, operaţionalizate sub forma a 30 de situaţii stresante specifice, care pot fi întâlnite la locul de muncă şi care generează sau favorizează tensiunea psihologică. JSS evaluează severitatea percepută (,intensitatea”) şi frecvenţa producerii acestor 30 de situaţii generatoare de stres.

Atunci când răspund la itemii JSS, indivizii evaluează mai întâi severitatea pe care o percep şi o atribuie fiecăreia din cele 30 de situaţii potenţial stresante, prin compararea acesteia cu o situaţie stresantă standard (definită prin instructaj ca fiind „Repartizarea unor sarcini neplăcute”). După evaluarea severităţii percepute a celor 30 de situaţii stresante, participanţii evaluează cât de des sa produs fiecare situaţie stresantă în timpul ultimelor 6 luni.

Se poate discuta aşadar în JSS despre Severitatea stresului şi Frecvenţa stresului, dar produsul lor relevă şi Indicele de stres ocupaţional. Pentru fiecare item (eveniment stresant) se calculează un astfel de indice, care se obţine ca produs al frecvenţei şi severităţii şi care pune în evidenţă gradul de stres ocupaţional resimţit de către indivizii evaluaţi, în ariile evaluate de JSS. De asemenea, JSS relevă (ca scale specifice) două componente majore ale stresului ocupaţional: Presiunea stresului (Job Pressure, JP) şi Lipsa sprijinului organizaţional (Lack of Support, LS). Aceste scale au fiecare doar câte 10 itemi; scala JP evaluează presiunile asociate cu munca în sine, iar scala LS evaluează presiunile asociate cu lipsa de sprijin din partea superiorilor, colegilor sau politicilor şi procedurilor administrative ale organizaţiei.

Prin urmare, JSS are trei indicatori (Severitate-S, Frecvenţă-F şi Index-X) pentru fiecare din cele trei arii: Presiune-JP, SprijinLS şi Stres general-JS. Cele nouă subscale ale sale sunt notate în consecinţă ca fiind: pentru scorul general al stresului JS-X 
(Indicele de stres ocupaţional), JS-S (Severitatea stresului) şi JS-F (Frecvenţa stresului), pentru presiunea stresului JP-X (Indicele de presiune la locul de muncă), JP-S (Severitatea presiunii) şi JP-F (Frecvenţa presiunii), iar pentru lipsa sprijinului organizaţional LS-X (Indicele lipsei de sprijin organizaţional), LS-S (Severitatea lipsei de sprijin organizaţional) şi LS-F (Frecvenţa lipsei de sprijin organizaţional).

\section{Metodă}

\section{Procedură}

JSS a fost tradus pentru prima oară în scopul utilizării acestuia în domeniul cercetării în România în anul 2003 de profesorul Horia Pitariu în cadrul unui program de cercetare desfăşurat la Universitatea Babeş-Bolyai din Cluj-Napoca. În 2008 versiunea din 2003 a fost reverificată prin două cicluri de traducere şi retroversiune independente.

În timpul celor 14 luni cuprinse între Februarie 2008 şi Aprilie 2009 au fost culese datele normative pentru România, atât prin procedură creion-hârtie cât şi prin administrare electronică (online). Proporţia celor două tipuri de administrare a fost aproximativ egală. Participanţilor li $\mathrm{s}-\mathrm{a}$ explicat scopul experimental al aplicării şi s-a obţinut de la aceştia consimţământul informat. Principalul obiectiv al colectării datelor normative a fost asigurarea unei distribuţii cât mai extinse printr-un număr de participanţi din cât mai multe organizaţii şi nu doar a asigurării unui volum mare de aplicări. S-a dorit maximizarea caracteristicilor naţionale conţinute de date şi minimizarea caracteristicilor organizaţionale. Astfel, nu au fost utilizate în studiile pentru eşantionul normativ românesc al JSS mai mult de 25 de administrări din aceeaşi organizaţie.

\section{Participanţi}

Eşantionul normativ românesc JSS este format dintr-un număr de $\mathrm{N}=1533$ de persoane provenind dintr-un număr total de 108 organizaţii din toată ţara. Dintre acestea, un număr de $\mathrm{N}=741$ de persoane $(48.34 \%$ din eşantionul total) sunt de sex masculin, iar un număr de $\mathrm{N}=792$ de persoane $(51.66 \%$ din eşantionul total) sunt de sex feminin. Vârsta participanţilor este cuprinsă între 18 şi 63 de ani, cu o medie $\mathrm{m}=35.01$ şi o mediană de 30 de ani.

Participanţii pot fi împărţiţi în patru categorii de vârstă: 18-30 ani, 31-40 ani, 41-50 ani şi 51-63 ani. Cea mai bine reprezentată este categoria de vârstă $18-30$ de ani (779 persoane, $50.82 \%$ din eşantionul total), în timp ce în categoria de vârstă 41-50 ani (233 persoane, $15.20 \%$ din eşantionul total) se încadrează cele mai puţine persoane.

În fiecare dintre cele 108 organizaţii a fost administrat JSS atât personalului fără funcţii manageriale (staff), cât şi personalului managerial (în cea mai mare majoritate manageri de nivel scăzut sau mediu). Personalul managerial a reprezentat $25.18 \%$ din eşantion (386 persoane), în timp ce restul personalului a reprezentat $74.82 \%$ din eşantion (1147 persoane). De asemenea, pentru a surprinde cât mai adecvat caracteristicile stresului ocupaţional în România, aplicările au fost colectate atât din organizaţii din mediul privat (807 persoane, $52.64 \%$ din eşantionul total), cât şi din organizaţii din mediul public (726 persoane, $47.36 \%$ din eşantionul total). Toate aceste date au fost interpretate atât împreună, cât şi separat, pentru a determina particularizat sursele de stres în funcţie de nivelul ierarhic în organizaţie şi în funcţie de tipul de organizaţie.

Pe lângă eşantionul normativ propriuzis a mai fost utilizat în studiu şi un eşantion de manageri de top, care a cuprins un număr de $\mathrm{N}=53$ persoane, dintre care $\mathrm{N}=35(66 \%$ din eşantion) de sex masculin şi $\mathrm{N}=18$ (34\% din eşantion) de sex feminin. Vârsta participanţilor a fost cuprinsă între 29 şi 64 de ani, cu o mediană de 44 ani.

\section{Rezultate şi discuţii}

\section{Fidelitatea JSS}

Fidelitatea JSS a fost studiată cu ajutorul coeficienţilor de consistenţă internă Cronbach alpha, calculaţi pentru eşantionul normativ total ( $\mathrm{N}=1553$ persoane) şi pentru eşantioanele masculin ( $\mathrm{N}=741$ persoane) şi feminin $(\mathrm{N}=792$ persoane $)$ considerate separat.

Coeficienţii de consistenţă internă Cronbach alpha sunt prezentaţi în Tabelul 1. Aceştia se încadrează între un minim de .78 pentru eşantioanele feminin şi combinat ale subscalei Frecvenţa lipsei sprijinului (LS-F) şi un maxim de .91 pentru toate eşantioanele pentru scala Severitatea stresului (JS-S) şi pentru eşantionul masculin şi total al Indicelui de stres ocupaţional (JS-X). 
Tabelul 1. Coeficienţii de consistenţă internă Cronbach alpha pentru JSS în România

\begin{tabular}{llll}
\hline \multirow{2}{*}{ Scală } & \multicolumn{3}{c}{ Eşantion } \\
\cline { 2 - 4 } & Masculin & Feminin & Combinat \\
\hline JS-X & .91 & .90 & .91 \\
JS-S & .91 & .91 & .91 \\
JS-F & .89 & .88 & .89 \\
JP-X & .81 & .80 & .81 \\
JP-S & .81 & .83 & .82 \\
JP-F & .82 & .83 & .83 \\
LS-X & .83 & .81 & .82 \\
LS-S & .84 & .83 & .84 \\
LS-F & .79 & .78 & .78 \\
\hline
\end{tabular}

Toţi coeficienţii de consistenţă internă iau valori peste .70 , pragul minim necesar recomandat de literatura de specialitate pentru ca testul să poată fi utilizat în siguranţă. Indicele de stres ocupaţional (JS-X), care reprezintă scorul total al testului, precum şi scala Severitatea stresului (JS-S), prezintă coeficienţi foarte înalţi, de peste .90. Acest lucru înseamnă că scorul total al testului poate fi utilizat, în cazul unei persoane evaluate, pentru luarea a unor decizii de importanţă majoră legate de nivelul său de stres ocupaţional.
Prin comparaţie cu coeficienţii de consistenţă internă ob̧̧inuţi pentru eşantionul normativ american (Spielberger \& Vagg, 1999), eşantionul românesc prezintă valori uşor mai înalte pentru scalele JS-X şi JS-S şi pentru subscala LS-X şi valori uşor mai scăzute pentru subscalele LS-F, JP-S şi JP-F. Este de remarcat faptul că pentru scorul total al testului (JS-X) coeficienţii de consistenţă internă sunt mai înalţi decât cei obţinuţi pentru eşantioanele americane corespondente, depăşind şi pragul de .90 .

\section{Validitatea JSS}

Corelaţii între scalele JSS. Corelaţiile între scalele şi subscalele JSS sunt prezentate în Tabelul 2. Nivelul cel mai redus de intercorelaţie între o scală/subscală şi restul scalelor este cel al subscalei JP-S (.17), iar cel mai înalt este cel al scalei JS-X (.92). Toate corelaţiile între scale/subscale sunt semnificative la un prag de semnificaţie statistică $p \leq .01$. Cea mai înaltă intercorelaţie se înregistrează între subscalele LS-X şi LS-F (.94), iar cea mai redusă între subscalele JP-S şi JP-F (.12). Media intercorelaţiilor pentru toate cele 9 scale şi subscale este de .53. Acest scor demonstrează o corelaţie înaltă între scale şi prin urmare omogenitatea ridicată a constructului de stres ocupaţional pe care îl măsoară.

Tabelul 2. Corelaţiile între scalele JSS pentru eşantionul normativ românesc ( $N=1533)$

\begin{tabular}{llllllllll}
\hline Scală & JS-X & JS-S & JS-F & JP-X & JP-S & JP-F & LS-X & LS-S & LS-F \\
\hline JS-X & 1 & .51 & .92 & .83 & .44 & .72 & .87 & .45 & .82 \\
JS-S & & 1 & .26 & .42 & .80 & .17 & .43 & .88 & .27 \\
JS-F & & & 1 & .76 & .18 & .84 & .80 & .27 & .85 \\
JP-X & & & & 1 & .52 & .85 & .50 & .27 & .48 \\
JP-S & & & & & 1 & .12 & .26 & .48 & .17 \\
JP-F & & & & & & 1 & .45 & .18 & .49 \\
LS-X & & & & & & & 1 & .49 & .94 \\
LS-S & & & & & & & & & .29 \\
LS-F & & & & & & & & & \\
\hline
\end{tabular}


Atunci când corelaţiile interscale sunt analizate pentru diferite grupuri criteriu conţinute în eşantionul normativ românesc, media intercorelaţiilor celor 9 scale şi subscale sunt următoarele: $r=.50$ pentru eşantionul de persoane angajate în organizaţii private; $r=.55$ pentru eşantionul de persoane angajate în organizaţii publice; $r=.61$ pentru eşantionul de manageri de nivel mediu; $r=.49$ pentru eşantionul format din persoane din staff-ul organizaţiilor.

Analiza factorială exploratorie. A fost efectuată 0 analiză factorială exploratorie asupra celor 20 itemi ai Severităţii, Frecvenţei şi Indicelui JSS scoraţi în subscalele Presiunea la locul de muncă şi Lipsa sprijinului organizaţional. Analiza a fost efectuată atât pentru eşantionul total combinat, cât şi separat pentru eşantioanele masculin şi feminin. A fost utilizată metoda recomandată de autor, Principal Axis Factoring. Asupra datelor obţinute a fost aplicată o rotaţie Promax cu o normalizare Kaiser. La utilizarea criteriul de stopare bazat pe saturaţia supraunitară a factorilor au fost obţinute, în toate cele trei cazuri, soluţii cu patru factori, dintre care doi puternici şi doi slabi. Soluţia cea mai adecvată, sugerată şi de analiza graficului saturaţiilor („scree plot'), a fost cea cu doi factori. Aceste soluţii justifică între $31.52 \%$ (indicele JSS, eşantion masculin) şi $36.00 \%$ (Severitatea JSS, eşantion feminin) din varianţa totală a scorurilor.

Tabelul 3. Saturaţiile itemilor Severităţii, Frecvenţei şi Indicelui JSS în factorii Presiunea la locul de muncă şi Lipsa sprijinului organizaţional pentru eşantionul normativ românesc (eşantion total, subeşantion masculin şi subeşantion feminin)

\begin{tabular}{|c|c|c|c|c|c|c|c|c|c|c|c|c|c|c|c|c|c|c|}
\hline \multirow{3}{*}{ Item } & \multicolumn{6}{|c|}{ Severitate } & \multicolumn{6}{|c|}{ Frecvenţă } & \multicolumn{6}{|c|}{ Indice JSS } \\
\hline & \multicolumn{2}{|c|}{ Combinat } & \multicolumn{2}{|c|}{ Masculin } & \multicolumn{2}{|c|}{ Feminin } & \multicolumn{2}{|c|}{ Combinat } & \multicolumn{2}{|c|}{ Masculin } & \multicolumn{2}{|c|}{ Feminin } & \multicolumn{2}{|c|}{ Combinat } & \multicolumn{2}{|c|}{ Masculin } & \multicolumn{2}{|c|}{ Feminin } \\
\hline & LS & $\mathrm{JP}$ & LS & $\mathrm{JP}$ & LS & $\mathrm{JP}$ & LS & $\mathrm{JP}$ & LS & $\mathrm{JP}$ & LS & $J P$ & LS & $\mathrm{JP}$ & LS & $\mathrm{JP}$ & LS & $J P$ \\
\hline Item 4 & & .60 & & .57 & & .62 & .51 & & .46 & & .53 & & & .46 & & .38 & & .50 \\
\hline Item 7 & .25 & .38 & (.31) & .32 & & .44 & .44 & & .43 & & .44 & & & .40 & & .41 & & .38 \\
\hline Item 9 & & .47 & & .43 & & .51 & .50 & & .48 & & .51 & & & .41 & & .38 & & .43 \\
\hline Item 11 & & .69 & & .62 & & .75 & .68 & & .71 & & .66 & & & .65 & & .65 & & .65 \\
\hline Item 16 & & .50 & & .51 & & .50 & .60 & & .58 & & .63 & & & .63 & & .66 & & .60 \\
\hline Item 23 & .49 & $(.22)$ & .51 & .23 & .48 & $(.22)$ & .45 & & .41 & & .47 & & $(.22)$ & .36 & $(.25)$ & .34 & $(.21)$ & .38 \\
\hline Item 24 & & .72 & & .73 & & .71 & .76 & & .76 & & .75 & & & .69 & & .72 & & .67 \\
\hline Item 25 & & .53 & & .55 & & .51 & .57 & & .60 & & .53 & & & .58 & & .57 & & .58 \\
\hline Item 26 & & .72 & & .72 & & .73 & .68 & & .67 & & .67 & & & .70 & & .68 & & .71 \\
\hline Item 27 & & .42 & & .37 & & .47 & .43 & & .35 & & .48 & & & .43 & & .33 & & .51 \\
\hline Item 3 & .58 & & .65 & & .51 & & & .43 & & .47 & & .39 & .46 & & .56 & & .38 & \\
\hline Item 5 & .36 & & .44 & & .30 & & .31 & $(.27)$ & $(.28)$ & .29 & .32 & $(.27)$ & .33 & & .36 & & .30 & \\
\hline Item 6 & .71 & & .73 & & .68 & & & .72 & & .70 & & .74 & .73 & & .69 & & .76 & \\
\hline Item 8 & .58 & & .56 & & .60 & & & .56 & & .51 & & .60 & .61 & & .58 & & .62 & \\
\hline Item 10 & .54 & & .53 & & .55 & & & .28 & & .28 & & .27 & .26 & & .24 & & .28 & \\
\hline Item 13 & .75 & & .73 & & .75 & & & .64 & & .61 & & .66 & .65 & & .63 & & .67 & \\
\hline Item 14 & .67 & & .63 & & .70 & & & .59 & & .62 & & .58 & .61 & & .62 & & .61 & \\
\hline Item 18 & .53 & & .52 & & .53 & & & .39 & & .38 & & .39 & .48 & & .50 & & .46 & \\
\hline Item 21 & .69 & & .70 & & .68 & & & .69 & & .72 & & .67 & .69 & & .68 & & .69 & \\
\hline Item 29 & .44 & & .43 & & .44 & & & .42 & & .44 & & .40 & .43 & & .46 & & .42 & \\
\hline
\end{tabular}

Notă: $\quad$ Sunt prezentate saturaţiile cele mai înalte cu valori mai înalte de .30. Între paranteze sunt prezentate alte saturaţii relevante. $\mathrm{C}=$ =şantion combinat; $\mathrm{F}=\mathrm{femei}$; $M=$ bărbaţi. 
Soluţiile factoriale sunt prezentate în Tabelul 3. În cazul Severităţii şi Indicelui JSS, primul factor corespunde Lipsei sprijinului organizaţional, iar al doilea factor corespunde Presiunii locului de muncă. În cazul Frecvenţei situaţia este inversată, primul factor corespunzând Presiunii locului de muncă, iar cel de-al doilea Lipsei sprijinului organizaţional.

După cum se poate observa, cu excepţia a doi itemi, cele două soluţii factoriale corespund itemilor prescrişi în cheia de scorare a subscalelor Presiunea la locul de muncă şi Lipsa sprijinului organizaţional. Una dintre excepţii este itemul 23, „Întreruperi frecvente ale activităţii de muncă", care este scorat pe subscala Presiunea locului de muncă, însă obţine pentru eşantionul românesc saturaţii mai înalte pentru Severitate în factorul Lipsa sprijinului organizaţional. Cea de-a doua excepţie este itemul 5, „Neîndeplinirea sarcinilor de către colegi”, care este scorat pe subscala Presiunea locului de muncă, dar care în două cazuri obţine saturaţii mai înalte în factorul Lipsa sprijinului organizaţional.

Analiza factorială confirmatorie. Analiza factorială confirmatorie a fost efectuată cu ajutorul programului EQS (Bentler, 2005). $\mathrm{Au}$ fost supuşi analizei cei 20 de itemi ai subscalelor Presiunea locului de muncă şi Lipsa sprijinului organizaţional, cu scopul de a confirma soluţia factorială cu doi factori prezentată mai sus. Rezultatele iniţiale au fost următoarele: la analiza Severităţii a fost obţinut un indice $\mathrm{CFI}=.848$ şi o rădăcină a pătratelor erorilor $\quad \mathrm{RMSEA}=.106, \quad \mathrm{X} 2(35)=641.290$, $p=.000$; la analiza Frecvenţei a fost obţinut un indice $\mathrm{CFI}=.904$ şi o rădăcină a pătratelor erorilor RMSEA $=.086, \quad \mathrm{X} 2(35)=435.585$, $\mathrm{p}=.000$; la analiza Indicelui stresului a fost obţinut un indice $\mathrm{CFI}=.884$ şi o rădăcină $\mathrm{a}$ pătratelor erorilor RMSEA $=.087$, $\mathrm{X} 2(35)=444.809, \quad p=.000$. După luarea în considerare a unor corelaţii între anumite erori aferente măsurării unora dintre variabilele modelului, au fost obţinute următoarele rezultate: Severitate - CFI=.914, RMSEA $=.082$, $x 2(35)=397.835, \quad p=.000 ; \quad$ Frecvenţă CFI=.911, RMSEA $=.073, \quad \chi 2(35)=3225.463$, $\mathrm{p}=.000$; Indicele stresului - $\mathrm{CFI}=.906$, RMSEA $=.078, \chi 2(35)=3479.154, p=.000$.

\section{Diferenţe demografice}

În Tabelul 4 sunt ilustrate mediile şi abaterile standard obţinute pentru eşantionul normativ românesc JSS, pentru subeşantioanele sale, precum şi pentru eşantionul de top manageri $(\mathrm{N}=53)$.

Tabelul 4. Mediile şi abaterile standard pentru eşantionului normativ românesc JSS (N=1533) şi pentru un eşantion de top manageri $(\mathrm{N}=53)$.

\begin{tabular}{|c|c|c|c|c|c|c|c|c|c|c|c|c|c|c|c|c|}
\hline \multirow{2}{*}{ Scală } & \multicolumn{2}{|c|}{ Masculin } & \multicolumn{2}{|c|}{ Feminin } & \multicolumn{2}{|c|}{ Combinat } & \multicolumn{2}{|c|}{$\begin{array}{l}\text { Manageri de } \\
\text { nivel mediu }\end{array}$} & \multicolumn{2}{|l|}{ Staff } & \multicolumn{2}{|c|}{ Mediu privat } & \multicolumn{2}{|c|}{ Mediu public } & \multicolumn{2}{|c|}{ Top manageri } \\
\hline & $\mathrm{M}$ & SD & M & SD & $\mathrm{M}$ & SD & $\mathrm{M}$ & SD & M & SD & M & SD & M & SD & M & SD \\
\hline JS-X & 18.79 & 10.84 & 20.03 & 10.63 & 19.43 & 10.75 & 20.30 & 12.65 & 19.14 & 10.01 & 19.40 & 9.95 & 19.47 & 11.58 & 27.21 & 9.00 \\
\hline JS-S & 5.08 & 1.16 & 5.26 & 1.09 & 5.18 & 1.13 & 5.22 & 1.22 & 5.16 & 1.10 & 5.19 & 1.08 & 5.16 & 1.19 & 5.49 & .97 \\
\hline JS-F & 3.46 & 1.70 & 3.67 & 1.63 & 3.57 & 1.66 & 3.64 & 1.89 & 3.54 & 1.58 & 3.59 & 1.55 & 3.55 & 1.79 & 4.78 & 1.35 \\
\hline$J P-X$ & 20.29 & 12.87 & 23.03 & 13.18 & 21.71 & 13.10 & 21.78 & 14.61 & 21.68 & 12.56 & 22.33 & 12.56 & 21.01 & 13.65 & 34.03 & 9.78 \\
\hline JP-S & 4.77 & 1.32 & 4.92 & 1.27 & 4.85 & 1.30 & 4.85 & 1.38 & 4.85 & 1.27 & 4.91 & 1.23 & 4.79 & 1.36 & 5.44 & 1.06 \\
\hline$J P-F$ & 4.05 & 2.18 & 4.58 & 2.18 & 4.32 & 2.19 & 4.30 & 2.41 & 4.33 & 2.12 & 4.43 & 2.09 & 4.20 & 2.30 & 6.18 & 1.49 \\
\hline LS-X & 18.13 & 13.49 & 18.82 & 13.38 & 18.49 & 13.44 & 20.19 & 15.07 & 17.92 & 12.79 & 17.92 & 12.40 & 19.12 & 14.48 & 23.14 & 13.11 \\
\hline LS-S & 5.32 & 1.41 & 5.51 & 1.30 & 5.42 & 1.36 & 5.51 & 1.39 & 5.39 & 1.34 & 5.43 & 1.31 & 5.41 & 1.41 & 5.46 & 1.40 \\
\hline LS-F & 3.13 & 2.00 & 3.18 & 1.96 & 3.16 & 1.98 & 3.32 & 2.17 & 3.10 & 1.91 & 3.10 & 1.85 & 3.22 & 2.11 & 3.95 & 1.91 \\
\hline
\end{tabular}

În funcţie de gen. Femeile prezintă un nivel de stres ocupaţional semnificativ mai înalt decât bărbaţii. Astfel, cu două excepţii, subscalele LS-X şi LS-F, femeile obţin scoruri mai ridicate decât bărbaţii la toate scalele şi subscalele JSS. Femeile prezintă: un indice de stres ocupaţional JS-X mai înalt $(\mathrm{t}=2.25$, $p \leq .05$ ); severitatea stresului JS-S mai ridicată $(\mathrm{t}=3.07, \mathrm{p} \leq .01)$; frecvenţa stresului JS-F mai înaltă $(\mathrm{t}=2.52, p \leq .01)$; indicele de presiune a stresului JP-X mai ridicat $(t=.4 .12, p \leq .001)$; severitatea presiunii stresului JP-S mai înaltă 
$(\mathrm{t}=2.27, \mathrm{p} \leq .001)$; frecvenţa presiunii stresului JP-F mai ridicată $(t=4.76, p \leq .001)$; severitatea lipsei sprijinului organizaţional LS-S mai înaltă $(\mathrm{t}=2.73, \mathrm{p} \leq .01)$

Tabelul 5. Mediile şi abaterile standard pentru scorurile la cei 30 itemi ai scalelor JS-X, JS-S şi JS-F ale eşantionului normativ românesc

\begin{tabular}{|c|c|c|c|c|c|c|c|c|c|c|c|c|c|c|c|c|c|c|}
\hline \multirow{3}{*}{ Item } & \multicolumn{6}{|c|}{ Severitate } & \multicolumn{6}{|c|}{ Frecvenţă } & \multicolumn{6}{|l|}{ Indice } \\
\hline & \multicolumn{2}{|c|}{ Feminin } & \multicolumn{2}{|c|}{ Masculin } & \multicolumn{2}{|c|}{ Combinat } & \multicolumn{2}{|c|}{ Feminin } & \multicolumn{2}{|c|}{ Masculin } & \multicolumn{2}{|c|}{ Combinat } & \multicolumn{2}{|c|}{ Feminin } & \multicolumn{2}{|c|}{ Masculin } & \multicolumn{2}{|c|}{ Combinat } \\
\hline & M & $S D$ & $\mathrm{M}$ & $S D$ & M & $S D$ & M & $S D$ & M & SD & $M$ & SD & M & $S D$ & M & SD & M & SD \\
\hline 1 & 4.95 & 1.29 & 4.72 & 1.50 & 4.84 & 1.40 & 4.15 & 3.38 & 3.71 & 3.36 & 3.94 & 3.38 & 20.81 & 18.34 & 18.08 & 18.78 & 19.49 & 18.60 \\
\hline 2 & 4.54 & 2.00 & 4.24 & 2.20 & 4.39 & 2.10 & 5.38 & 3.61 & 4.45 & 3.68 & 4.93 & 3.67 & 24.21 & 20.40 & 19.31 & 20.03 & 21.84 & 20.37 \\
\hline 3 & 6.43 & 2.03 & 6.04 & 2.30 & 6.24 & 2.17 & 3.73 & 4.00 & 3.64 & 3.94 & 3.68 & 3.97 & 24.85 & 28.86 & 23.55 & 28.01 & 24.23 & 28.45 \\
\hline 4 & 4.16 & 1.90 & 4.09 & 1.97 & 4.13 & 1.93 & 4.96 & 3.36 & 4.22 & 3.45 & 4.60 & 3.42 & 20.26 & 17.64 & 16.97 & 17.14 & 18.67 & 17.48 \\
\hline 5 & 5.20 & 1.95 & 5.30 & 2.02 & 5.25 & 1.98 & 3.98 & 3.33 & 3.87 & 3.38 & 3.93 & 3.36 & 22.07 & 21.92 & 21.65 & 21.67 & 21.87 & 21.80 \\
\hline 6 & 5.88 & 1.93 & 5.58 & 2.21 & 5.73 & 2.07 & 3.35 & 3.42 & 3.21 & 3.42 & 3.28 & 3.42 & 21.05 & 23.70 & 19.76 & 23.49 & 20.43 & 23.60 \\
\hline 7 & 5.96 & 1.89 & 5.65 & 2.03 & 5.81 & 1.97 & 4.26 & 3.29 & 3.91 & 3.36 & 4.09 & 3.33 & 25.70 & 22.76 & 23.15 & 22.84 & 24.47 & 22.82 \\
\hline 8 & 5.71 & 1.90 & 5.36 & 2.18 & 5.54 & 2.04 & 2.81 & 3.18 & 2.73 & 3.16 & 2.77 & 3.17 & 16.72 & 20.97 & 15.58 & 20.24 & 16.17 & 20.62 \\
\hline 9 & 4.85 & 2.00 & 4.87 & 2.26 & 4.86 & 2.13 & 4.83 & 3.65 & 4.30 & 3.60 & 4.58 & 3.64 & 23.56 & 22.02 & 21.40 & 22.00 & 22.51 & 22.03 \\
\hline 10 & 5.34 & 2.15 & 5.30 & 2.28 & 5.32 & 2.22 & 2.47 & 3.29 & 3.22 & 3.55 & 2.83 & 3.44 & 14.84 & 21.86 & 19.07 & 24.02 & 16.88 & 23.02 \\
\hline 11 & 4.93 & 2.02 & 4.79 & 2.17 & 4.86 & 2.10 & 5.22 & 3.35 & 4.73 & 3.49 & 4.99 & 3.43 & 25.65 & 21.15 & 22.97 & 21.48 & 24.36 & 21.35 \\
\hline 12 & 4.73 & 2.29 & 4.54 & 2.40 & 4.64 & 2.34 & 2.34 & 3.18 & 2.08 & 3.11 & 2.22 & 3.14 & 12.01 & 19.61 & 10.56 & 18.59 & 11.31 & 19.13 \\
\hline 13 & 6.08 & 2.21 & 5.77 & 2.37 & 5.93 & 2.29 & 2.26 & 2.98 & 2.15 & 2.99 & 2.21 & 2.98 & 14.72 & 21.21 & 13.72 & 21.08 & 14.24 & 21.14 \\
\hline 14 & 5.41 & 2.16 & 5.10 & 2.33 & 5.26 & 2.25 & 3.27 & 3.31 & 2.96 & 3.36 & 3.12 & 3.34 & 19.64 & 22.72 & 16.89 & 22.56 & 18.31 & 22.68 \\
\hline 15 & 5.64 & 1.95 & 5.49 & 2.09 & 5.57 & 2.02 & 3.99 & 3.56 & 3.86 & 3.61 & 3.93 & 3.58 & 24.60 & 25.10 & 23.33 & 25.20 & 23.99 & 25.15 \\
\hline 16 & 5.34 & 1.90 & 4.96 & 2.13 & 5.16 & 2.03 & 3.91 & 3.16 & 4.00 & 3.37 & 3.95 & 3.26 & 21.05 & 19.37 & 20.50 & 21.21 & 20.79 & 20.27 \\
\hline 17 & 6.36 & 2.54 & 5.93 & 2.77 & 6.15 & 2.66 & 1.30 & 2.43 & 1.96 & 2.99 & 1.62 & 2.74 & 8.51 & 17.20 & 12.36 & 21.26 & 10.37 & 19.36 \\
\hline 18 & 4.74 & 2.03 & 4.72 & 2.14 & 4.73 & 2.09 & 2.97 & 3.54 & 3.00 & 3.52 & 2.99 & 3.53 & 15.22 & 20.31 & 15.16 & 20.08 & 15.19 & 20.19 \\
\hline 19 & 6.52 & 2.06 & 6.53 & 2.04 & 6.52 & 2.05 & 4.04 & 3.91 & 4.52 & 3.91 & 4.27 & 3.92 & 28.16 & 29.76 & 31.82 & 30.87 & 29.93 & 30.35 \\
\hline 20 & 5.06 & 2.04 & 4.91 & 2.20 & 4.99 & 2.12 & 2.23 & 3.26 & 2.17 & 3.18 & 2.20 & 3.22 & 12.36 & 20.34 & 12.16 & 19.69 & 12.26 & 20.02 \\
\hline 21 & 5.44 & 2.02 & 5.31 & 2.09 & 5.38 & 2.06 & 3.02 & 3.30 & 2.84 & 3.26 & 2.93 & 3.28 & 17.62 & 21.52 & 16.29 & 20.80 & 16.97 & 21.18 \\
\hline 22 & 5.29 & 2.40 & 5.30 & 2.35 & 5.29 & 2.38 & 3.52 & 3.62 & 3.46 & 3.61 & 3.50 & 3.62 & 20.36 & 24.30 & 20.37 & 24.39 & 20.36 & 24.33 \\
\hline 23 & 5.21 & 2.09 & 5.05 & 2.24 & 5.13 & 2.17 & 4.11 & 3.62 & 3.78 & 3.64 & 3.95 & 3.63 & 22.44 & 23.22 & 20.67 & 22.92 & 21.59 & 23.08 \\
\hline 24 & 4.48 & 1.98 & 4.45 & 2.14 & 4.46 & 2.06 & 4.90 & 3.43 & 4.18 & 3.48 & 4.55 & 3.47 & 21.75 & 19.00 & 19.08 & 19.89 & 20.46 & 19.48 \\
\hline 25 & 4.70 & 2.12 & 4.78 & 2.24 & 4.74 & 2.17 & 4.45 & 3.61 & 3.84 & 3.60 & 4.15 & 3.62 & 22.85 & 22.95 & 20.25 & 23.39 & 21.59 & 23.19 \\
\hline 26 & 4.89 & 2.05 & 4.69 & 2.09 & 4.79 & 2.07 & 5.07 & 3.46 & 4.16 & 3.55 & 4.63 & 3.53 & 25.64 & 22.05 & 20.77 & 21.77 & 23.29 & 22.04 \\
\hline 27 & 4.71 & 2.23 & 4.42 & 2.27 & 4.57 & 2.25 & 4.08 & 3.63 & 3.38 & 3.53 & 3.74 & 3.60 & 21.40 & 23.06 & 17.12 & 21.83 & 19.33 & 22.57 \\
\hline 28 & 5.35 & 2.06 & 5.16 & 2.14 & 5.26 & 2.10 & 3.86 & 3.21 & 3.82 & 3.40 & 3.84 & 3.30 & 21.64 & 21.20 & 21.15 & 22.01 & 21.40 & 21.59 \\
\hline 29 & 4.90 & 2.08 & 4.75 & 2.07 & 4.83 & 2.07 & 3.99 & 3.48 & 3.64 & 3.45 & 3.82 & 3.47 & 21.48 & 22.41 & 19.65 & 21.67 & 20.60 & 22.07 \\
\hline 30 & 5.03 & 2.18 & 4.72 & 2.33 & 4.88 & 2.26 & 1.68 & 2.71 & 1.90 & 2.83 & 1.78 & 2.77 & 9.60 & 17.31 & 10.48 & 17.79 & 10.02 & 17.54 \\
\hline
\end{tabular}


Stresul ocupaţional mai înalt al femeilor poate fi observat şi prin analiza scorurilor obţinute la itemii individuali (Tabelul 5). În ceea ce priveşte Severitatea, femeile obţin scoruri semnificativ mai înalte decât bărbaţii la un număr de 12 itemi. Şi Frecvenţa situaţiilor stresante este resimţită mai acut de către femei (11 itemi). Bărbaţii apreciază ca fiind mai frecvente lipsa echipamentelor de care au nevoie în activitatea lor (itemul 10), insultele personale din partea superiorilor şi colegilor (itemul 17), precum şi salariul mai redus (itemul 19). Aceşti trei itemi obţin şi Indici ai itemilor mai înalţi în cazul bărbaţilor. Şi în cazul Indicilor itemilor femeile prezintă scoruri semnificativ mai mari decât bărbaţii la un număr de 10 itemi, dintre care 7 aparţin subscalei Presiunea stresului (JP-X).

În funcţie de nivelul funcţiei deţinute. La compararea scorurilor subeşantionului de manageri de nivel mediu (middle level) cu cele ale eşantionului format din persoane cu funcţii de execuţie (staff), apare o singură diferenţă semnificativă din punct de vedere statistic. Aceasta se înregistrează în cazul subscalei LS-X. Rezultatele arată că managerii de nivel mediu resimt un nivel al lipsei sprijinului organizaţional semnificativ mai înalt decât eşantionul de persoane din staff $(\mathrm{t}=2.66$, $p \leq .01)$.

Faţă de personalul fără funcţii manageriale, managerii de nivel mediu resimt mai sever unele trăiri negative faţă de organizaţie (itemul 14) şi o slabă motivaţie din partea colegilor (itemul 29). Se manifestă de asemenea mai frecvent în cazul acestora absenţa recunoaşterii performanţelor bune (itemul 8) şi trăiri negative faţă de organizaţie. $\mathrm{Ca}$ Indici globali ai situaţiilor stresante, sunt obţinute scoruri mai înalte de către managerii de nivel mediu la aceiaşi itemi 8 şi 14, precum şi la itemii 21 („Control şi îndrumare slabă sau inadecvată") şi 28 (Efectuarea muncii unui alt angajat"). Toţi aceşti itemi aparţin subscalei LS-X şi vin să confirme scorurile $t$ obţinute pentru diferenţele scorurilor scalelor şi subscalelor.

A fost efectuată şi o comparaţie între mediile obţinute de eşantionul de top manageri şi eşantionul de manageri de nivel mediu. Conform rezultatelor obţinute, funcţia de top manager aduce cu sine un nivel al stresului ocupaţional global (scala JS-X) semnificativ mai înalt decât funcţia de manager de nivel mediu ( $\mathrm{t}=4.96, \mathrm{p} \leq .001)$. De asemenea, top managerii prezintă scoruri mai înalte la Frecvenţa stresului (JS-F) $(t=5.42, p \leq .001)$,
Indicele de presiune a stresului (JP-X) ( $\mathrm{t}=7.98$, $\mathrm{p} \leq .001)$, Severitatea presiunii (JP-S) $(\mathrm{t}=3.65$, $\mathrm{p} \leq .001)$, Frecvenţa presiunii (JP-F) $(\mathrm{t}=7.89$, $p \leq .001)$ şi Frecvenţa lipsei de sprijin organizaţional $(t=1.99, p \leq .05)$. După cum era de aşteptat, în special datorită libertăţii decizionale de care beneficiază top managerii, sursele stresului ocupaţional mai înalt decât cel al managerilor de nivel mediu ţin în mare parte de sarcinile propriu-zise şi mult mai puţin de sprijinul organizaţional. Trebuie menţionat însă faptul că aceste analize ar trebui tratate cu precauţ̧ie şi reluate şi pentru alte eşantioane de top manageri, dat fiind numărul redus de participanţi incluşi în acest eşantion.

În ceea ce priveşte severitatea situaţiilor stresante individuale, top managerii obţin scoruri semnificativ mai înalte la un număr de 8 dintre cele 30 de situaţii, dintre care 7 aparţin subscalei Presiunea locului de muncă (JP-X). De partea cealaltă, managerii de nivel mediu obţin un scor semnificativ mai înalt la itemul 18, „Absenţa participării în luarea deciziilor privind politica organizaţiei". $\mathrm{Ca}$ frecvenţă de apariţie a situaţiilor stresante, 17 dintre acestea au o frecvenţă de apariţie mai mare în cazul top managerilor, dintre care toate cele 10 situaţii componente ale scalei Presiunea locului de muncă (JP-X). Cu o singură excepţie (itemul 8 , care nu mai atinge pragul de semnificaţie statistică), această stare de fapt se înregistrează şi în ceea ce priveşte indicii itemilor. Indicele itemului 18 este mai înalt pentru managerii de nivel mediu decât pentru managerii de nivel înalt $(\mathrm{t}=4.64$, $\mathrm{p} \leq .001)$.

În funcţie de tipul de organizaţie. Luând în considerare criteriul tipului de organizaţie din care provin participanţii, se remarcă diferenţe semnificative din punct de vedere statistic între mediile obţinute la două dintre subscalele JSS. Astfel, persoanele din mediul privat prezintă un nivel mai înalt al Frecvenţei presiunii (JP-F) decât cele din mediul public ( $\mathrm{t}=2.03, \mathrm{p} \leq .05)$, precum şi un Indice al presiunii mai înalt $(t=1.96, p \leq .05)$.

Persoanele din mediul privat resimt ca fiind mai grave decât persoanele din mediul public situaţiile descrise de itemii 3 („Lipsa posibilităţilor de promovare”) şi 25 („Prea multe hârtii de completat"). În ceea ce priveşte frecvenţa de apariţie a situaţiilor stresante, în mediul privat apar mai frecvent decât în mediul public necesitatea efectuării de ore suplimentare (itemul 2) şi lipsa timpului pentru probleme personale (itemul 27), în timp ce în mediul public se manifestă cu o mai mare 
frecvenţă absenţa participării la luarea de decizii privind politica organizaţiei (itemul 18), un salariu considerat inadecvat (itemul 19) şi colegi de muncă slab motivaţi (itemul 29). Din perspectiva Indicelui itemilor (adică a surselor generale de stres), orele suplimentare (itemul 2) şi sarcinile cu responsabilităţi crescute (itemul 11) apar mai adesea în mediul privat, în timp ce unele trăiri negative cu privire la organizaţie (itemul 14), precum şi cele trei situaţii deja menţionate, anume absenţa participării la luarea de decizii privind politica organizaţiei (itemul 18), salariul inadecvat (itemul 19) şi colegi de muncă slab motivaţi (itemul 29), constituie factori de stres mai mare în mediul public decât în mediul privat.

În funcţie de vârstă. Evoluţia în timp a stresului ocupaţional a fost studiată prin analiza diferenţelor între scorurile medii JSS obţinute pentru cele 4 categorii de vârstă luate în considerare: $18-30$ ani $(\mathrm{N}=779), 31-40$ ani $(\mathrm{N}=237), \quad 41-50$ ani $(\mathrm{N}=233), \quad 51-63$ ani $(\mathrm{N}=284)$. Se poate observa în general o uşoară tendinţă de scădere a scorurilor odată cu vârsta (în special în cazul scalelor LS-X, LS-S, LS-F), fără a atinge însă cu excepţia câtorva cazuri pragul de semnificaţie statistică. Este de remarcat faptul că acea componentă a stresului care scade mai accentuat între prima şi a doua grupă de vârstă este severitatea. Acest lucru este de aşteptat, deoarece persoanele din prima grupă de vârstă, care abia intră în câmpul muncii, în perioada de acomodare şi de acumulare a competenţelor de bază pentru meseria lor, percep ca fiind mai stresante sarcinile şi relaţiile de muncă presupuse de slujba lor. Astfel, grupa de vârstă 18-30 ani prezintă niveluri mai înalte ale scorurilor decât grupa de vârstă 31-40 ani la următoarele: scala JS-S $(\mathrm{t}=3.93, \mathrm{p} \leq .001)$; subscala JP-S ( $\mathrm{t}=2.15, \mathrm{p} \leq .01)$; subscala LS-S $(t=3.60, p \leq .001)$.

În continuare, pentru celelalte grupe de vârstă, nu se mai evidenţiază decât o singură scădere semnificativă din punct de vedere statistic a scorurilor JS-S. Aceasta se înregistrează pentru subscala JP-F între grupele de vârstă 31-40 ani şi 41-50 ani $(t=2.54, p \leq .001)$. Este de remarcat faptul că nivelul Indicelui de stres ocupaţional nu suferă transformări semnificative din punct de vedere statistic, nici în sensul creşterii, nici în sensul scăderii, odată cu înaintarea în vârstă.

\section{Diferenţe culturale}

Diferenţele culturale au fost studiate prin compararea scorurilor obţinute pentru eşantionul românesc de manageri de nivel mediu cu cele obţinute pentru eşantionul american de manageri/specialişti şi a scorurilor eşantionului de persoane fără funcţii executive (staff) românesc cu cele de personal administrativ şi de întreţinere (Tabelul 6). Potrivit descrierilor componenţei celor două eşantioane americane din manualul testului, acestea par să corespundă celor două eşantioane româneşti.

Tabelul 6. Valorile scorurilor t corespunzătoare diferenţelor între scorurile medii la scalele şi subscalele JSS ale eşantionului normativ american şi ale eşantionului normativ românesc

\begin{tabular}{|c|c|c|c|c|c|c|c|c|c|c|}
\hline \multirow[t]{2}{*}{ Scală } & \multicolumn{2}{|c|}{$\begin{array}{l}\text { Manageri/specialişti } \\
\text { americani }\end{array}$} & \multicolumn{2}{|c|}{$\begin{array}{l}\text { Manageri de nivel } \\
\text { mediu, români }\end{array}$} & \multirow[t]{2}{*}{$t$} & \multicolumn{2}{|c|}{$\begin{array}{l}\text { Personal } \\
\text { administrativ/de } \\
\text { întreţinere american }\end{array}$} & \multicolumn{2}{|c|}{$\begin{array}{l}\text { Personal de } \\
\text { execuţie român }\end{array}$} & \multirow[t]{2}{*}{$t$} \\
\hline & $M$ & $S D$ & $\mathrm{M}$ & SD & & $M$ & SD & $M$ & SD & \\
\hline JS-X & 20.19 & 10.06 & 20.30 & 12.65 & -.15 & 19.65 & 12.40 & 19.14 & 10.01 & .97 \\
\hline JS-S & 4.92 & 1.03 & 5.22 & 1.22 & $-4.27^{* * *}$ & 4.85 & 1.33 & 5.16 & 1.10 & $-5.44^{* * *}$ \\
\hline JS-F & 3.69 & 1.63 & 3.64 & 1.89 & .46 & 3.38 & 1.81 & 3.54 & 1.58 & $-2.03^{*}$ \\
\hline JP-X & 22.62 & 12.40 & 21.78 & 14.61 & .99 & 21.18 & 14.46 & 21.68 & 12.56 & -.78 \\
\hline JP-S & 4.52 & 1.27 & 4.85 & 1.38 & $-4.05^{\star \star *}$ & 4.62 & 1.47 & 4.85 & 1.27 & $-3.55^{* * *}$ \\
\hline JP-F & 4.57 & 2.14 & 4.30 & 2.41 & 1.92 & 3.99 & 2.29 & 4.33 & 2.12 & $-3.33^{* * *}$ \\
\hline LS-X & 20.15 & 14.37 & 20.19 & 15.07 & -.04 & 19.52 & 16.01 & 17.92 & 12.79 & $2.33^{*}$ \\
\hline LS-S & 5.49 & 1.36 & 5.51 & 1.39 & -.24 & 5.28 & 1.63 & 5.39 & 1.34 & -1.55 \\
\hline LS-F & 3.23 & 2.06 & 3.32 & 2.17 & -.70 & 3.03 & 2.17 & 3.10 & 1.91 & -.74 \\
\hline
\end{tabular}


Potrivit rezultatelor obţinute, managerii români prezintă un nivel mai înalt de Severitate a stresului $(t=4.27, p \leq .001)$ şi de Severitate a presiunii $(\mathrm{t}=4.05, \quad \mathrm{p} \leq .001)$ decât managerii americani. Personalul fără funcţii executive român prezintă o Severitate a stresului mai înaltă ( $t=5.44, p \leq .001)$, o Frecvenţă a stresului mai înaltă $(\mathrm{t}=2.03, \mathrm{p} \leq .05)$, o Severitate a presiunii mai înaltă $(\mathrm{t}=3.55, \mathrm{p} \leq .001)$ şi $\mathrm{o}$ Frecvenţă a presiunii mai înaltă $(t=.3 .33$, $p \leq .001)$ decât personalul similar din eşantionul american. De cealaltă parte, personalul fără funcţii executive din eşantionul american înregistrează un Indice al lipsei sprijinului organizaţional mai înalt decât cel român $(\mathrm{t}=2.33, \mathrm{p} \leq .05)$. Este de remarcat faptul că nu se înregistrează diferenţe în ceea ce priveşte Indicele de stres ocupaţional (JS-X).

La studierea comparativă a surselor principale de stres ocupaţional în cele două structuri se remarcă faptul că există diferenţe destul de mari între eşantioanele studiate; diferenţele se manifestă în ambele sensuri, atât ca şi medii obţinute, cât şi în ceea ce priveşte clasamentele itemilor. Pentru manageri, următoarele 11 situaţii prezintă un indice mai înalt pentru americani decât pentru români: întreruperi frecvente ale activităţii de muncă (itemul 23), prea multe hârtii de completat (itemul 25), prea multe sarcini cu termene fixe (itemul 26), conflicte cu alte departamente (itemul 30), absenţa participării în luarea deciziilor privind politica organizaţiei (itemul 18), personal insuficient pentru realizarea unor sarcini (itemul 15), echipament neadecvat sau de slabă calitate (itemul 10), neîndeplinirea sarcinilor de către colegi (itemul 5), trăirea unor atitudini negative faţă de organizaţie (itemul 14), confruntarea cu situaţii de criză (itemul 7) şi absenţa recunoaşterii performanţelor bune (itemul 8). Următoarele 12 situaţii prezintă un indice mai înalt pentru managerii români decât pentru cei americani: timp insuficient pentru probleme personale (itemul 27), schimbări frecvente de la activităţi de rutină la activităţi solicitante (itemul 24), relaţii dificile cu superiorii direcţi (itemul 13), efectuarea muncii unui alt angajat (itemul 28), repartizarea unor sarcini neplăcute (itemul 1), perioade de inactivitate (itemul 12), efectuarea de sarcini care nu se găsesc în fişa postului (itemul 9), sarcini cu responsabilităţi crescute (itemul 11), control şi îndrumare slabă sau inadecvată (itemul 21), lipsa posibilităţilor de promovare (itemul 3), repartizarea unor sarcini noi/nefamiliare (itemul 4) şi sprijin ineficient din partea şefului (itemul 6).
Apar diferenţe şi în ceea ce priveşte clasamentul situaţiilor stresante. Pentru managerii americani cea mai stresantă este situaţia cuprinsă în itemul 23, întreruperi frecvente ale activităţii de muncă, care în cazul managerilor români se situează abia pe pozitiia a zecea. Pe poziţiile doi şi trei se situează prea multe sarcini cu termene fixe (locul 8 la managerii români) şi personal insuficient pentru realizarea unor sarcini (locul 2 la managerii români). Pentru managerii români pe primele trei locuri se află salariul inadecvat (locul 5 la americani), personal insuficient pentru realizarea unor sarcini (locul 3 la americani) şi lipsa posibilităţilor de promovare (abia locul 15 la americani). Pe locul 4 la managerii americani se află situaţia 25 , prea multe hârtii de completat, care, la români, se situează abia pe locul 19.

Personalul fără funcţii administrative din eşantionul american obţine medii semnificativ mai înalte decât cel român pentru următoarele 12 situaţii stresante: întreruperi frecvente ale activităţii de muncă (itemul 23), salariu inadecvat (itemul 19), absenţa participării în luarea deciziilor privind politica organizaţiei (itemul 18), absenţa recunoaşterii performanţelor bune (itemul 8), neîndeplinirea sarcinilor de către colegi (itemul 5), colegi de muncă slab motivaţi (itemul 29), echipament neadecvat sau de slabă calitate (itemul 10), insulte personale din partea superiorilor, colegilor, consumatorilor (itemul 17), prea multe hârtii de completat (itemul 25), trăirea unor atitudini negative faţă de organizaţie (itemul 14), prea multe sarcini cu termene fixe (itemul 26) şi conflicte cu alte departamente (itemul 30). Românii - din eşantionul similar, cu funcţii de execuţie - obţin scoruri mai înalte decât americanii pentru următoarele 11 situaţii stresante: ore suplimentare (itemul 2), repartizarea unor sarcini neplăcute (itemul 1), sarcini cu responsabilităţi crescute (itemul 11), repartizarea unor sarcini noi/nefamiliare (itemul 4), luarea unor decizii critice/rapide (itemul 16), relaţii dificile cu superiorii direcţi (itemul 13), timp insuficient pentru probleme personale (itemul 27), confruntarea cu situaţii de criză (itemul 7), control şi îndrumare slabă sau inadecvată (itemul 21), sprijin ineficient din partea şefului (itemul 6), efectuarea de sarcini care nu se găsesc în fişa postului (itemul 9).

În clasamentul general al itemilor, la americani pe primele trei poziţii se situează salariul inadecvat (ca şi la români), întreruperi frecvente ale activităţii de muncă (pe locul 11 la români) şi neîndeplinirea sarcinilor de către 
colegi (locul 10 la români). La români, pe primele locuri se situează salariul inadecvat, sarcinile cu responsabilităţi crescute (locul 18 la americani) şi confruntarea cu situaţii de criză (locul 12 la americani).

\section{Limitări şi concluzii}

Studiul de faţă are valorile sale, acestea ţinând în primul rând de volumul şi calitatea eşantionului utilizat. În mod special dorim să scoatem în evidenţă coerenţa cu care varianta românească a JSS se compară cu varianta originală a chestionarului, în ceea ce priveşte indicatorii psihometrici (Spielberger, Reheiser, Reheiser \& Vagg, 1999), comparaţiile inter-grupuri (Turnage \& Spielberger, 1991), corelaţiile interscale (Spielberger, 1991), comparaţiile între diverse categorii profesionale sau de nivel (Spielberger \& Reheiser, 1994) etc.

Totuşi, dorim să scoatem în evidenţă şi unele limitări. În primul rând, trebuie menţionată imposibilitatea de a eşantiona în mod coerent organizaţiile utilizate la colectarea datelor. În al doilea rând, designul studiului este unul constatativ, nonexperimental; concluziile trase au fost susţinute doar de comparaţii statistice între subgrupuri şi nu permit generalizări în anumite cazuri. De exemplu, diferenţele dintre diversele categorii de vârstă nu permit concluzii reale despre evoluţia în timp a nivelului de stres ocupaţional, datele nefiind colectate printr-un design longitudinal. În al treilea rând, calităţile psihometrice ale chestionarului nu sunt investigate în întregime. De exemplu, nu este verificată stabilitatea test-retest; nu sunt discutate validitatea de criteriu, sau validitatea predictivă; nu este analizată convergenţa cu alte chestionare similare şi divergenţa $\mathrm{cu}$ diverse concepte cvasi-similare. În al patrulea rând, nu este investigată superioritatea pe care autorii chestionarului pretind că formatul JSS o are asupra formatului tradiţional utilizat de alte chestionare care evaluează stresul ocupaţional. În plus, nu este pus în evidenţă avantajul care este obţinut în termenii măsurării constructului, prin agregarea frecvenţei şi severităţii evenimentelor stresante.

Cercetări viitoare ar trebui să ia în considerare posibilitatea de a eşantiona riguros atât organizaţii cât şi indivizi, pe anumite criterii relevante pentru manifestarea stresului ocupaţional. Ar fi de dorit ca JSS să fie investigat din punctul de vedere al caracteristicilor sale psihometrice şi în designuri experimentale, ori în designuri longitudinale, ori în designuri corelaţionale mai complexe, prin raportare la criterii diverse.

\section{Bibliografie}

Cooper, C. L., Sloan, S. G. \& Williams, S. (1988). The Occupational Stress Indicator: Management guide. Windsor, England: NFER-Nelson.

Dewe, P. J. (1989). Examining the nature of work stress: Individual evaluations of stressful experiences and coping. Human Relations, 42, 993-1013.

Edwards, J. R. \& Cooper, C. L. (1990). The personenvironment fit approach to stress: Recurring problems and some suggested solutions. Journal of Organizational Behavior, 11, 293-307.

French, J. R. P., Jr. \& Caplan, R. D. (1972). Occupational stress and individual strain. In A. J. Marrow (Ed.), The failure of success (pp. 30-66). New York: Amacon.

French, J. R. P., Jr., Caplan, R. D. \& Harrison, R. V. (1982). The mechanisms of job stress and strain. Chichester, England: Wiley.

Hackman, J. R. \& Lawler, E. E. (1971). Employee reactions to job characteristics. Journal of Applied Psychology, 55, 259-285.

Hackman, J. R. \& Oldham, G. R. (1975). Development of the Job Diagnostic Survey. Journal of Applied Psychology, 60, 159170.

Insel, P. M. \& Moos, R. H. (1974). Work Environment Scale, Form R. Palo Alto, CA: Consulting Psychologists Press.

Karasek, R. A., Jr. (1979). Job demands, job decision latitude and mental strain: Implications for job redesign. Administrative Science Quarterly, 24, 285-308.

Lazarus, R. S. (1991). Psychological stress in the workplace. In P. L. Parrewé (Ed.), Handbook on job stress (pp. 1-13). Corte Madera, CA: Select Press.

Osipow, S. H. \& Spokane, A. R. (1987). Occupational Stress Inventory manualresearch version. Odessa, FL: Psychological Assessment Resources.

Osipow, S. H. (1998). Occupational Stress Inventory-Revised: Professional manual. Odessa, FL: Psychological Assessment Resources.

Spielberger, C. D. \& Reheiser, E. C. (1994). Job stress in university, corporate, and military personnel. International Journal of Stress Management, 1, 19-31. 
Spielberger, C. D. (1991). Preliminary test manual for the Job Stress Survey (JSS). Odessa, FL: Psychological Assessment Resources.

Spielberger, C. D., \& Vagg, P. R. (1999). Test manual for the Job Stress Survey (JSS). Odessa, FL: Psychological Assessment Resources.

Spielberger, C. D., Reheiser, E. C, Reheiser, J. E. \& Vagg, P. R. (1999). Measuring stress in the workplace: The Job Stress Survey. In D. T.
Kenny, J. G. Carlson, F. T. McGuigan \& J. L. Sheppard (Eds.), Stress and health: Research and clinical applications (pp. 481-496). Ryde, Australia: Gordon \& Breach, Science Publisher/Harwood Academic Publishers.

Turnage, J. J. \& Spielberger, C. D. (1991). Job stress in managers, professionals, and clerical workers. Work \& Stress, 5, 165176. 